\title{
IMPACT OF PHYSICAL LIMITATION IN LIFE QUALITY HEALTH RELATED OF HEART FAILURE PATIENTS
}

\author{
IMPACTO DA LIMITAÇÃO FÍSICA NA QUALIDADE DE VIDA RELACIONADA À \\ SAÚDE DE PACIENTES COM INSUFICIÊNCIA CARDÍACA
}

\author{
Paula Cristina SILVA ${ }^{1}$; Bruno Fagundes dos SANTOS ${ }^{2}$; Omar Pereira de ALMEIDA NETO ${ }^{3}$; \\ Cristiane Martins CUNHA ${ }^{4}$; Elmiro Santos RESENDE; \\ Leila Aparecida Kauchakje PEDROSA ${ }^{6}$ \\ 1. Mestranda em Ciências da Saúde, Universidade Federal de Uberlândia - UFU, Uberlândia, MG, Brasil; 2. Enfermeiro, \\ UFU, Uberlândia, MG, Brasil; 3. Doutorando em Atenção à Saúde - UFTM, Professor na Unidade de Ciências da Saúde - \\ Universidade Federal de Goiás; 4. Doutora em Ciências - EERP/USP, Professora na Faculdade de Medicina - UFU, \\ Uberlândia, MG, Brasil; 5. Doutor em Cardiologia, Professor na Faculdade de Medicina UFU, Uberlândia, MG, Brasil; 6. \\ Doutora em Enfermagem, Professora na Universidade Federal do Triângulo Mineiro.
}

\begin{abstract}
The heart failure (HF) it's a self-limiting and severe condition, of varied etiology, with negative repercussions to the political-economic framework, and to health related life quality (HRLQ) of patients with HF, due to its standard symptoms and effects. Its's believed that due to the reduced cardiorespiratory competence coming for the HF, certain physical limitation levels would be expressed, impairing directly the HRLQ. To evaluate the physical limitation impact in the HRLQ of Heart Failure patients. Cross-sectional study, quantitative, descriptive and analytical character, conducted with patients treated at a Cardiology outpatient clinic from a university hospital. To evaluate the patients was used: characterization questionnaire Clinic and Socioeconomic, Minnesota Living With Heart Failure Questionnaire (MLHFQ) and the Veterans Specific Activity Questionnaire (VSAQ). The data was managed in Microsoft Office Excel® 2010 program, double independent entry. Subsequently imported into Statistical Package for Social Science program (SPSS), version 21.0, which were conducted exploratory analyzes of data from the calculation of simple absolute and percentage frequencies for categorical variables and measures of centrality and dispersion for quantitative variables, as well as parametric testing Pearson correlation, since the normal distribution of variables. In the research were included 108 patients, with a predominance of female participants $(50.90 \%)$, mean age of $66.55 \pm 11.41$ years. Regarding the NYHA functional classification at level II (50\%) and NYHA III (39.80\%) were the most prevalent. The etiologies of HF was the most prevalent Chagas' Heart (50.90\%). The MLHFQ showed negative impact of the IC under the HRLQ, which presented a total score of MLHFQ of $51.87 \pm 15.74$ points. At the physical limitation the VSAQ resulted in an average of 3, 37 $\pm 1,41$ with bigger impairment to the METS3 (45, 4\%). The MLHFQ and VSAQ correlation presented itself negative, moderate to strong and significant $(\mathrm{p}<0,01)$ it results for each domain being: physical $(-0,523)$; emotional $(-0.436)$; nonspecific $(-$ 0,411), and MLHFQ's total score $(-0,562)$. It has been confirmed that the greater the degree of heart damage due to HF presents, the lower will be the patient's MET results confirming a physical limitation as a HRLQ's impairing predictor.
\end{abstract}

KEYWORDS: Heart Failure. Life Quality. Physical Capacity

\section{INTRODUCTION}

Heart diseases (HD) are one of the world's most common causes of death (WHO, 2011). It stands as the third most common hospitalization cause in Brazil' health system, Sistema Único de Saúde (SUS) from which Heart Failure (HF) is the most frequent of those (BOCCHI et al., 2012; BRASIL, 2012a; BRASIL, 2012b).

$\mathrm{HF}$ is a severe, self-limiting and multi etiological condition when the heart muscle lacks the strength to sustain the body tissue's nutrition and oxygen support (SPINAR et al., 2011; LATUF, 2013; DIAS et al., 2015).

It's known that the HF's main consequences regarding its symptoms are the dyspnea, the edema and the fatigue related to the physical limitation, which due to its pathophysiology there is a cardiac output reduction and an increase from both, lung and systemic venous pressure, leading to functional capability's deficits, the last being an important HD's mortality predictor and prognostic marker (DI NASO et al., 2011; DIAS et al., 2015).

Inside this context some instruments have been developed aiming to evaluate HF patient's physical limitation. Among those methods there's the HF's functional classification from New York Heart Association (NYHA), which is based according with the symptoms presented by the patient when performing daily activities, varying from I to IV and the Veterans Specific Activity Questionnaire (VSAQ), which is an instrument able to measure the HF's physical limitation though metabolic equivalents (METs) (MYERS et al., 1994; DOMINGUES, 2010; DI NASO et al., 2011). Each MET represents an increase of $10 \%$ in the 
survival rate, meaning that the higher the MET result, the better the patient's aerobical capability is, as well as its functional performance (COELHORAVAGNANI et al., 2013).

It's believed that the HF's physical repercussions have direct influence in the individual's social relationships and emotional aspects, directly and indirectly affecting its live quality (LQ) and resulting in a HRLQ's impairment. In this context, the measurement of the HF patient's HRLQ becomes important due to the possibility to evaluation and/or comparison of the clinical interventions effects (MONTEIRO et al., 2010; SANTOS et al., 2012).

Recently the research of the physical limitation's impact over the HRLQ has been increased in the international dimension. However, despite it's an important marker and HRLQ influencer, there are very few researches developed and the physical aptitude instruments and the HF patient's HRLQ evaluation are not normally used in the national literature (DOMINGUES, 2010; SPINAR et al., 2011; DIAS et al., 2015).

It's already known that researches regarding this type of subjects (LQ and physical limitation evaluation) may present valuable information when establishing parameters, making possible the construction of an situational diagnosis for each patient aiming to identify its needs and risks, help in the health professional approach, improve the health team's communication, and verify the health results in pre-developed goals and objectives (DI NASO et al., 2011). In this context the objective of this research was to evaluate the physical limitation impact in HF patient's HRLQ.

\section{MATERIAL AND METHODS}

\section{Research type, Population and Ethic aspects}

Cross-sectional study, quantitative, descriptive and analytical character, conducted with patients treated at a Cardiology outpatient clinic from a university hospital from Minas Gerais (MG), approved by the Ethics and Research Committee with Human under protocol $\mathrm{n}^{\circ} 1.240 .465$, conducted with HF patients, older than 18 years old who haven't been admitted to the hospital in the last 30 days.

\section{Applicants Recruiting and Data Collect Instruments}

It has been developed a pilot study to ten patients how fit in the requirements to participate in the study, and obtained a total sample of 108 patients, the collecting period stretched out from December 2015 until February 2016.

Through the consent form's singing, the participants answered the instruments questions, beginning with the instrument named, Clinical and Socio-demographic Characterization Questionnaire (DE ALMEIDA NETO; PEDROSA, 2015). Next, It's been utilized the Minnesota Living With Heart Failure's (MLHFQ) Brazilian validated version, for HRLQ's measurement (RECTOR; COHN, 1992; CARVALHO et al., 2009). And finally it was applied the VSAQ's Brazilian validated version in order to quantify de HD patient's physical limitation corresponding MET (MYERS et al., 1994; DOMINGUES, 2010).

\section{Data Managing and Statistical Analysis}

The data were managed in the Program Microsoft Office Excel ${ }^{\circledR} 2010$, followed by its data bank validation. Afterwards, the data were imported to the Statistical Package for the Social Science (SPSS $®)$ software, 20.0 version, for statistical analysis. Exploratory analysis of the data were made after the definition of the absolute simple and percentage frequencies to de categorical variables and centrality and dispersion measures to the quantitative variables. The Cronbach $\alpha$ internal consistency measures were used to verification of MLHFQ's results. In order to verify the relation between the quantitative variables (MLHFQ/VSAQ), Pearson's correlation test was applied. A significance level equals $5 \%(\mathrm{p} \leq 0,05)$ was adopted to the bivariate analyzes. The correlations were classified as: weak $(0<\mathrm{r}<0,3)$, moderate $(0,3<\mathrm{r}<0,5)$ or strong $(\mathrm{r} \geq 0,5)$.

\section{RESULTS AND DISCUTION}

\section{Socioeconomic characteristics}

Were found in this study a prevalence of participants in white color, married, retired and from the female gender (Table 1).

The women prevalence diverge from other studies (NOGUEIRA; RASSI; CORRÊA, 2010; ALITI et al., 2011; LINDVALL; HULTMAN; JACKSON, 2014; ALMEIDA; GUTIERREZ; MARQUES, 2012). 
Table 1. Socioeconomic characteristics of the following categorical variables: sex, color, marital status, religion, work condition, from HD patients attended at the heart clinic of an university Hospital from MG since December 2015, until February 2016.

\begin{tabular}{lcc}
\hline \multicolumn{1}{c}{ VARIABLE } & $\mathbf{N}$ & $\%$ \\
\hline Sex & 55 & 50,90 \\
Female & 53 & 49,10 \\
Male & & \\
Color & 56 & 51,90 \\
White & 35 & 32,40 \\
Brown & 14 & 13,00 \\
Black & 3 & 2,80 \\
Yellow & & \\
Marital state & 58 & 53,70 \\
Married & 22 & 20,40 \\
Widower & 16 & 14,80 \\
Devorced & 12 & 11,10 \\
Single & & \\
Religion & 65 & 60,20 \\
Catolic & 30 & 27,80 \\
Evangelic & 6 & 5,60 \\
Spiritist & 5 & 4,60 \\
Other & 2 & 1,90 \\
No religion & & 88,00 \\
Work Condition & 95 & 6,50 \\
Retired & 7 & 5,60 \\
Active & 6 & $\mathbf{1 0 0}$ \\
Inactive & $\mathbf{1 0 8}$ & \\
\hline TOTAL & & \\
\hline
\end{tabular}

Source: O Author, 2016

The 2010 census from the Brazilian Institute of Geography and Statistics (IBGE) may justify the divergence above mentioned due to the bigger number of women living in the country (IBGE, 2010). Another explanation lays on the fact that the male population tends to delay the heath assistance exposing themselves to risky situations, more frequent hospitalization and other comorbidities (BARBOSA; JURKEVICZ, 2010).

\section{Clinical characteristics}

As observed in Table 3, the number of patients with NYHA I classification was very low, but this may be explained by the asymptomatic characteristic of this level classification. While those who got NYHA IV normally tend to skipping directly and frequently to hospital internment, which is not this research focus.

Table 3. Clinical characteristics from HF patients attended at the heart clinic of an university Hospital from MG since December 2015, until February 2016.

\begin{tabular}{lcc}
\hline \multicolumn{1}{c}{ VARIABLE } & N & \% \\
\hline NYHA Functional Class & 7 & 6,50 \\
I & 54 & 50,00 \\
II & 43 & 39,80 \\
III & 4 & 3,70 \\
IV & 55 & 50,90
\end{tabular}


Isquemic Heart disease

Hipertensive Heart disease

Valvular Heart disease

Idiopatic

\section{Medications}

Betablocker

Diuretic

ACEI / ARB

Antithrombotic

Estatin

Nitrate

Digitalic

Antidepressant / Axiolytic

\section{Comorbidities}

Chagas

Systemic artherial hipertension

Arrhithmia

Atrioventricular block

Dyslipidemia

Coronarian Artherial Desiese

Anxiety / Depression

Diabetes mellitus

Hipotireoidism

Angina

Atrial fibrilation

Stroke

Chronic renal failure

Obesity

Surgical Heart Procedure

Pacemaker

Angioplasty

Revascularization

Valvuloplasty

\section{Life Habits}

Physical Activite

Smoker

Ex-smoker

Alcoholic

Ex-Alcoholic

Heart Rehabilitation
26,90

11,10

5,60

5,60

58,30

64,80

57,40

42,60

24,10

22,20

17,60

16,70

59,30

52,80

28,70

25,00

15,70

14,80

14,80

12,00

8,30

8,30

7,40

5,60

5,60

4,60

75,90

19,40

5,60

1,90

2,80

12,00

25,90

9,30

18,50

Source: The Author, 2016.

The main HF cause identified in this study was the chagasic heart desiese $(55 ; 50,90 \%)$ followed by the isquemic heart desiese (29; $26,90 \%$ ), such data corroborate with the ones found by Nogueira, Rassi and Corrêa, (2010) and Porto, Rassi and Costa Neto, (2012). This data is justified by the prevalence of Chagas disease $(64 ; 59,30 \%)$ as main comorbidity found among the selected patients. According to $\mathrm{WHO}$, about sixteen to eighteen million people have Chagas disease in Latin America, in Brazil the number of infected it's close to five million people, with the highest

0

infection rates being of the southeast region (XAVIER et. al, 2015).

Following this reasoning, it's justifiable the surgical procedures most common at the study (Pacemaker 75,90\% and angioplasty 19,40\%), because the pace maker implant is a standard procedure in patients with Chagas disease, due to the damage caused on the cardiac muscle, generating clinical conditions of bradyarrhithmia, $\mathrm{VAB}$ and deficient sinus node conduction (GONZALEZ et. al, 2014.). 


\section{Health Related life quality in Heart Failure Patients}

The LQ evaluation is as important at the health area as in the generic scientific field, since its concept interposes to the health concept: satisfaction and wellbeing in all physical, socioeconomic and cultural scope (MONTEIRO et al., 2010; PEREIRA; TEIXEIRA; SANTOS, 2012).

At the HRLQ measurement, the MLHFQ presented the scores shown at Table 4 .

Table 4. MLHFQ's characteristics classified by domains and total score, from HF patients attended at the heart clinic of an university Hospital from MG since December 2015, until February 2016.

\begin{tabular}{lcccc}
\hline \multicolumn{1}{c}{ VARIABLE } & AVAREGE \pm SD & MINIMUN & MAXIMUN & CRONBACH'S ALFA \\
\hline Physical Domain & $25,27 \pm 8,86$ & 8 & 40 & 0,680 \\
Emotional Domain & $10,07 \pm 5,69$ & 0 & 25 & 0,789 \\
Unspecific Domain & $13,78 \pm 3,54$ & 6 & 21 & 0,816 \\
Minnesota Total & $51,87 \pm 15,74$ & 16 & 92 & 0,811 \\
\hline
\end{tabular}

Source: The Author, 2016.

The physical domain average score presented higher than other studies results which used the same instrument, varying between 7,9-17 points (SACCOMANN; CINTRA; GALLANI, 2011; LIMA; MORAIS, 2014).

According to MLHFQ's interpretation, the symptoms and physical limitations which disturbs the HF patient's work, recreation, autonomy and independence are identified by them as LQ reducers.

Regarding the emotional domain, the study shown a deterioration of the psychic aspects when compared with other cross-sectional studies performed at the states of São Paulo and Goiás which found 6,8 and 7,8 scores in the emotional evaluation respectively (SACCOMANN; CINTRA; GALLANI, 2011; LIMA; MORAIS, 2014). However another research found a higher value equal to 15,1 indicating a HRLQ loss in the emotional aspects (SANTOS; PLEWKA; BROFMAN, 2009).

The total average of MLHFQ remained high when compared with other studies where the maximum values got a variation from 34,95 to 38 , meaning that the patients included in this study presented higher HRLQ deficit (NOGUEIRA; RASSI; CORRÊA, 2010; SACCOMANN; CINTRA; GALLANI, 2011; LIMA; MORAIS, 2014).
A recent research regarding the general and specific HRLQ of HF patients and their socioeconomic profile in some University Hospital from the Triangulo Mineiro, presented very close results with the ones found at the present study (DE ALMEIDA NETO; PEDROSA, 2015). A possible result justification could be the fact that both studies were performed at the same region, therefore the population and data behavior were very likely to be similar. Another hypothesis would be the nonadhesion to the suggested therapeutic treatment as well as a multiprofessional treatment, which leads to a HRLQ loss aggravation.

\section{Physical limitation on Heart Failure patients}

There are very fill studies using the VSAQ (Table 5), initially being directed to patients with Lung Capacity Test (PCT) indication, this last considered the gold standard in functional capacity evaluation. Despite the direct measure being more precise and considered the main clinical measurement method, a big cut of the population doesn't get access to it, due to its high price, extended procedure time and great risk of cardiovascular events in HD patients (COOK et al., 2001; PIERSON et al., 2003; MCAULEY et al., 2006; ROCHA et al, 2006; DOMINGUES, 2010; CARVALHO et al., 2011).

Table 5. VSAQ instrument characteristics sorted by centrality measures, dispersion and simple frequency from HF patients attended at the heart clinic of an university Hospital from MG since December 2015, until February 2016.

\begin{tabular}{cccccc}
\hline VARIABLE & AVERAGE \pm SD & MINIMUN & MAXIMUN & N & \% \\
\hline VSAQ & $3,37 \pm 1,41$ & 1 & 8 & - & - \\
1 MET & - & - & & 5 & 4,6 \\
2 METS & - & - & & 20 & 18,5 \\
3 METS & - & - & & 49 & 45,4 \\
4 METS & - & - & & 13 & 12,0 \\
5 METS & - & - & & 2 & 13,0 \\
6 METS & - & - & & & 1,9
\end{tabular}


Source: The Author, 2016; MET: Metabolic Equivalent; METS: Metabolic Equivalents

The result presented by VSAQ's application in this study has presented itself lower than other studies (Table 5) meaning that the sample patients have higher functional loss and greater mortality risk (COOK et al., 2001; PIERSON et al., 2003; MCAULEY et al., 2006).

The patients shown physical capability to perform simple daily activities (eating, getting dressed, taking shower, walking slowly through small distances), an explanation for the VSAQ's low score could be the physical activity and heart rehabilitation low adhesion, found at this study (Table 3). It's know that physical inactivity generally leads to poor conditioning and reduced aerobial capability, especially in older subjects (MUELLA; BASSAN; SERRA, 2011; ALMEIDA et al., 2013; SILVEIRA; RIBEIRO; RAMIS, 2012).

\section{Specific HRLQ and VSAQ correlation}

There weren't any reference, either national or international making a MLHFQ and VSAQ correlation, until the reference revision of this study, making it the first of its kind.

The results obtained through Pearson's correlation, between VSAQ and MLHFQ domains, is justified by the HF's symptomatology and therapeutic characteristics themselves as above mentioned.

Table 6. Pearson's correlation between MLHFQ domains and VSAQ's score from HF patients attended at the heart clinic of an university Hospital from MG since December 2015, until February 2016

\begin{tabular}{lc}
\hline \multicolumn{1}{c}{ VARIABLE } & VSAQ \\
\hline Minnesota Physical Domain & $-0,523^{* *}$ \\
Minnesota Emotional Domain & $-0,436^{* *}$ \\
Minnesota Inespecific Domain & $-0,411^{* *}$ \\
Minnesota Total Score & $-0,562^{* *}$ \\
\hline
\end{tabular}

Source: O Author, 2016; **p $<0,01$

In this context the correlation presented strong and significant values between the MLHFQ domains and VSAQ's METS scores $(r=0,562)$ and negative due to the instruments inverse proportionality, while the lower the METS result, the higher the task execution difficulty, the same idea is expressed in the MLHFQ with higher results (PENA et al., 2011; SANTOS et al., 2011; SANTOS et al., 2015).

The predominance of NYHA functional class II and III in the study (Table 3 ) could be a justification since the higher NYHA classification, the more severe is the individual performance loss. This predominance also implies in a larger number of early retirement, work field removal, greater dependency to perform simple activities, which leads to emotional degradation, low self-esteem, depression and anxiety signals (PEREIRA et al., 2012).

\section{CONCLUSIONS}

The negative impact of the $\mathrm{HF}$ in all domains of the specific HRLQ were higher than previous studies involving the subject.

VSAQ's results show in this study were lower than any other study found, and they also prove the relationship between $\mathrm{HF}$ and physical capability limitation.

This study confirmed the hypothesis that the HF patients with higher classification (sorted by NYHA functional class and low LVEF) presents reduced METS, identifying the physical limitation as a low therapeutic adhesion predictor, disease maintenance loss and evolution, confirming its HRLQ negative impact.

Therefore, longitudinal studies using VSAQ and MLHFQ must be encouraged, in order to keep up with this population's possible changes in both METs and HRLQ, with the understanding that these instruments when associated with clinical and propaedeutic exams will converge in a better HF patient's situational diagnosis allowing better and more efficient ways of intervention and treatment for this patient type. 
RESUMO: A Insuficiência Cardíaca (IC) é uma condição grave e auto limitante, de etiologia variada, que reduz a qualidade de vida (QVRS), e esta entre as patologias que mais onera o sistema público de saúde, devido aos sinais e sintomas desencadeados e ao grande numero de internações devido as complicação da doença. Acredita-se que o desempenho cardiorrespiratório prejudicado pela IC expresse os níveis de limitação física e que impacte negativamente a QVRS. Avaliar o impacto da limitação física na QVRS de indivíduos com IC. Estudo transversal, de caráter quantitativo, descritivo e analítico, conduzido com pacientes atendidos no Ambulatório de Cardiologia de um Hospital Universitário. Para avaliação dos pacientes, utilizou-se: Questionário de caracterização Clínica e Socioeconômica, Minnesota Living With Heart Failure Questionnaire (MLHFQ) e o Veterans Specific Activity Questionnaire (VSAQ). Os dados foram gerenciados no Programa Microsoft Office Excel@ 2010, em dupla digitação independente. Posteriormente, importados para Programa Statistical Package for the Social Science (SPSS), versão 21.0, onde foram realizadas análises exploratórias dos dados a partir da apuração de frequências simples absolutas e percentuais para as variáveis categóricas e medidas de centralidade e de dispersão para variáveis quantitativas, assim como teste paramétrico de correlação de Pearson, visto a distribuição normal das variáveis. Foram inclusos no estudo 108 pacientes, com predomínio de participantes do sexo

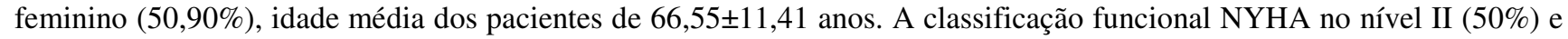
NYHA III $(39,80 \%)$ foram as mais evidenciadas, com predomínio da etiologia chagásica (50,90\%). O MLHFQ evidenciou

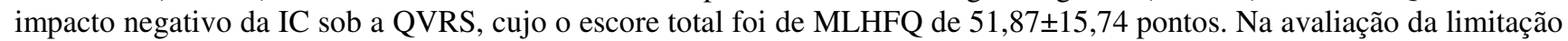

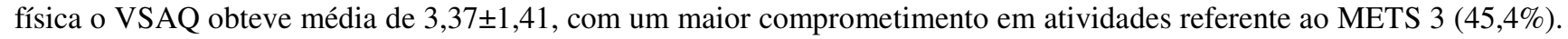
A correlação entre os domínios do MLHFQ e VSAQ mostrou-se negativa, moderada à forte e significante $(\mathrm{p}<0,01)$ para os domínios: físico (- 0,523); emocional (- 0,436); inespecífico (-0,411), e o escore total do MLHFQ (-0,562). A hipótese de que pacientes com maiores graus de IC e FEVE baixa apresentam MET reduzido foi confirmada, identificando a limitação física como um preditor para a piora na QVRS.

PALAVRAS-CHAVES: Doença Cardiaca. Qualidade de Vida. Capacidade Física.

\section{REFERENCES}

ALMEIDA, G. A. S.; TEIXEIRA, J. B. D. A.; BARRICHELLO, E.; BARBOSA, M. H. Perfil de saúde de pacientes acometidos por Insuficiência Cardíaca. Esc Anna Nery, São Paulo, v. 17, n. 2, p. 328-335, abr./jun 2013. https://doi.org/10.1590/S1414-81452013000200018

ALMEIDA, M. A. B.; GUTIERREZ, G. L.; MARQUES, R. Qualidade De Vida: definição, conceitos e interfaces com outras áreas de pesquisa. São Paulo: Escola de Artes, Ciências e Humanidades, 2012. 142p. Disponível em< http://each.uspnet.usp.br/edicoes-each/qualidade_vida.pdf.> Acesso em: 02 maio. 2015

ALITI, G. B.; LINHARES, J. C. C; LINCH, G. F. D. C; RUSCHEL, K. B; Eneida Rejane RABELO. Sinais e sintomas de pacientes com insuficiência cardíaca descompensada: inferência dos diagnósticos de enfermagem prioritários. Rev Gaúcha Enferm, Porto Alegre, v. 32, n. 3, p. 590-595, set. 2011. https://doi.org/10.1590/S1983-14472011000300022

BARBOSA, A. J.; JURKEVICZ, V. Acolhimento e integralidade na saúde do homem: uma reflexão a cerca dos desafios para a enfermagem. [S.L.; s.n], 2010. Não paginado

BOCCHI, E. A. et a; MARCONDES-BRAGA, F.G.;BACAL, F.; FERRAZ, A. S.; MESQUITA, E. T.; ALBUQUERQUE, D.; RODRIGUES, D. A.; VILAS-BOAS, F.; CUZ, F.; RAMIRES, F.; VILLACORTA JUNIOR, H.; SOUZA NETO, J.D.; ROSSI NETO, J.M.; MOURA, L. Z.; SILVA, L.B.D.; MOREIRA, L.F.; ROHDE, L.E.; MONTERA, M. W.; SIMÕES, M.V.; MORREIRA, M.D.C.; CLAUSELL, N.; BESTETTI, R.; MOURILHE-ROCHA, R.; MANGINI, S.; RASSI, S.; FERREIRA, S.M.A.; MARTINS, S.M.; BORDIGNON, S.; SARLI ISSA, V. Sociedade Brasileira de Cardiologia. Atualização da Diretriz Brasileira de Insuficiência Cardíaca Crônica - 2012. Arq Bras Cardiol, Brasil, v. 98, n. 1, p. 1-33, 2012. https://doi.org/10.1590/S0066782X2012000100001 https://doi.org/10.1590/S0066-782X2012001000001

BRASIL. (2012 a). Ministério da Saúde. Datasus. Indicadores e Dados Básicos. Disponível em: <http://tabnet.datasus.gov.br/cgi/tabcgi.exe?idb2012/c04.def>. Acesso em 25 abril. 2015. 
BRASIL. (2012 b). Ministério da Saúde. Datasus. Informações de Saúde. Internações por faixa etária, gênero e mortalidade por Insuficiência Cardíaca. Disponível em $<\mathrm{http} / / / \mathrm{w} w w$.datasus.gov.br $>$. Acesso em 23 ago. 2015.

CARVALHO, V. O.; GUIMARÃES, G. V.; CARRARA, D.; BACAL, F.; BOCHI, E.A. Validação da versão em português do Minnesota Living with Heart Failure Questionnaire. Arq Bras Cardiol, São Paulo, v. 93, n. 1, p. 39-44, 2009. https://doi.org/10.1590/S0066-782X2009000700008

CARVALHO, E. E. V.; COSTA, D. C.; CRESCÊNCIO, J. C.; SANTI, G.L.D.; PAPA, V.; MARQUES, F.; SCHMIDT, A.; MARIN-NETO, A.; SIMÕES, M.V.; GALLO JÚNIOR, L. Insuficiência Cardíaca: Comparação entre o Teste de Caminhada de seis Minutos e o Teste Cardiopulmonar. Arq Bras Cardiol, São Paulo, 2011. Não paginado. Disponível em: < http://www.scielo.br/pdf/abc/v97n1/aop04811.pdf> Acessado em: 02 de maio de 2015.

COELHO-RAVAGNANI1, C. D. F.; MELO, F. C. L.; RAVAGNANI, F.C. P.; BURINI, F. H. P.; BURINI, R.C. Estimativa do equivalente metabólico (MET) de um protocolo de exercícios físicos baseada na calorimetria indireta. Rev Bras Med Esporte, Cuiabá, v. 19, n. 2, p. 134-138, mar/abr. 2013. https://doi.org/10.1590/S1517-86922013000200013

COOK, J. W.; PIERSON, L. M.; HERBERT, W. G.; NORTON, H. J.; FEDOR, J. M.; KIEBZAK, G. M. et al. The influence of patient strength, aerobic capacity and body composition upon outcomes after coronary artery bypass grafting. Thorac Cardiovasc Surg, Califórnia, v. 49, n. 2, p. 89-93, abr. 2001. https://doi.org/10.1055/s-2001-11703

DE ALMEIDA NETO, O. P. D; PEDROSA, L. A. K. Qualidade de Vida Relacionada à Saúde de Pacientes com Insuficiência Cardíaca. 2015. 114f. Dissertação (Mestrado em Saúde do Adulto)- Pós-Graduação Stricto Sensu em Atenção à Saúde, Universidade Federal do Triângulo Mineiro, Uberaba, 2015.

DIAS, C. M. C. C.; LEMOS, A. Q.; ALBUQUERQUE, I. V. S.; BRASIL, C. A.; OLIVEIRA, F.T. O.; MACEDO, L. B. Qualidade de vida após sete anos do evento coronariano agudo. Revista Pesquisa em Fisioterapia, Salvador, v. 5, n. 2, p. 114-124, 2015.

DI NASO, F. C.; PEREIRA, J. S.; BEATRICCI, S. Z.; BIANCHI, R. G.; DIAS, A. S.; MONTEIRO, M. B. A classe da NYHA tem relação com a condição funcional e qualidade de vida na insuficiência cardíaca. Fisioterapia e Pesquisa, São Paulo, v. 18, n. 2, p. 157-63, 2011. https://doi.org/10.1590/S180929502011000200010

DOMINGUES, G. D. B. L. Adaptação cultural e validação do Veterans Specific Activity Questionnaire para população brasileira com sintomatologia cardiovascular. 2010. 136f. Dissertação (Mestrado em Ciências da Saúde) - Pós-Graduação em Enfermagem, Universidade Estadual de Campinas, Campinas, 2010.

GONZALEZ, B. et al. Factores de riesgo asociados con el diagnóstico de miocardiopatía chagásica crónica en individuos seropositivos del estado Barinas, Venezuela. Invest. clín, Maracaibo, v. 55, n. 2, p. 119132, jun. 2014.

INSTITUTO BRASILEIRO DE GEOGRAFIA E ESTATÍSTICA (IBGE). Censo demográfico 2010. Brasil, 2010. Disponível em: < http://www.ibge.gov.br/home /estatistica/populacao/censo2010/default.shtm> Acessado em: 20 de abril de 2016

LATUF, S. A. Insuficiência cardíaca. Jornal Cruzeiro do Sul, Sorocaba, 2013.Disponível: http://www.cruzeirodosul.inf.br/materia/464440/insuficiencia-cardiaca. Acessado: 01 de maio de 2015.

LIMA, P. B. D.; MORAIS, E. R. D. Qualidade de vida e nível de atividade física de pacientes portadores de insuficiência cardíaca crônica. ASSOBRAFIR Ciência. Goiânia, v. 5, n. 1, p. 27-39, 2014. 
LINDVALL, C.; HULTMAN, T.D.; JACKSON, V.A. Overcoming the Barriers to Palliative Care Referral for Patients With Advanced Heart Failure. Journal of the American Heart Association, [S.1.], v. 3, n. 1, fev. 2014. Disponivel em: < http://www.ncbi.nlm.nih.gov/pmc/articles/PMC3959710/> Acessado em: 15 maio 2015.

MCAULEY, P.; MYERS, J.; ABELLA, J.; FROELICHER, V. Evaluation of a specific activity questionnaire to predict mortality in men referred for exercise testing. Am Heart J, Palo Alto - CA, v. 151, n. 4, p. 890-897, 2006.

MONTEIRO, R. et al. Qualidade de vida em foco. Rev Bras Cir Cardiovasc., São Paulo, v. 25, n. 4, p. 568$74,2010$.

MUELLA, H. C. S.; BASSAN, R.; SERRA, S. M. Avaliação dos Benefícios Funcionais de um Programa de Reabilitação Cardíaca. Rev Bras Cardiol, São Paulo, v. 24, n. 4, p. 241-250, 2011.

MYERS, J.; DO, D.; HERBER, W.; RIBISL, P.; FROELICHER, V. F. A nomogram to predict exercise capacity from a specific questionnaire and clinical data. Am J Cardiol, v. 73, n. 8, p. 591-596, 1994. https://doi.org/10.1016/0002-9149(94)90340-9

NOGUEIRA, P. R.; RASSI, S.; CORRÊA, K. S. Perfil epidemiológico, clínico e terapêutico da insuficiência cardíaca em hospital terciário. Arq Bras Cardiol, Goiânia, v. 95, n. 3, p. 392-398, 2010. https://doi.org/10.1590/S0066-782X2010005000102

PENA, F. M.; AMORIM, A.; FASSBENDER, C. et al. Insuficiência cardíaca e depressão: uma associação com desfechos negativos. Insuficiencia Cardiaca, Buenos Aires, v. 6, n. 4, 2011. Não paginado

PEREIRA, D. A. G. et al. Capacidade funcional de indivíduos com insuficiência cardíaca avaliada pelo teste de esforço cardiopulmonar e classificação da New York Heart Association. Fisioter Pesq, Belo Horizonte, v. 19, n. 1, p. 52-56, 2012. https://doi.org/10.1590/S1809-29502012000100010

PEREIRA, E. F.; TEIXEIRA, C. S.; SANTOS, A. D. Qualidade de vida: abordagens, conceitos e avaliação.

Rev Bras Educ Fís Esporte, São Paulo, v. 26, n. 2, p. 241-50, abr./jun. 2012. https://doi.org/10.1590/S180755092012000200007

PIERSON, L. M.; NORTON, H. J.; HERBERT, W. G.; PIERSON, M. E.; RAMP, W. K.; KIEBZAK, G. M. et al. Recovery of self-reported functional capacity after coronary artery bypass surgery. CHEST, Charlotte, v. 123, n. 5, p. 1367-1374, 2003. https://doi.org/10.1378/chest.123.5.1367

PORTO, J. D.; RASSI, S.; COSTA NETO, S. B. Avaliação da qualidade de vida em pacientes com cardiopatia chagásica submetidos à terapia celular. 2012. Não paginado. Dissertação (Mestrado em Ciências da Saúde) - Pós-Graduação em Ciências da Saúde, Universidade Federal de Goiás, Goiânia, 2012.

RECTOR, T. S.; COHN, J. N. Assessment of patient outcome with the Minnesota Living With Heart Failure Questionnaire: reliability and validity during a randomized, double-blind, placebo-controlled trial of pimobendan. Am Heart J, [S.1], v. 124, n. 4, p. 1017-1025, 1992.

ROCHA, G. R.; STEIN, R.; GUIMARÃES MÁRCIO, R.; RIBEIRO, J. P. Resposta Cronotrópica ao Teste Cardiopulmonar após o Uso de Cimetidina. Arq Bras Cardiol, Porto Alegre, v. 86, n. 3, p. 206-210, 2006. https://doi.org/10.1590/s0066-782x2006000300008

SACCOMANN, I. C. R.; CINTRA, F. A.; GALLANI, M. C. B. J. Qualidade de vida relacionada à Saúde em Idosos com Insuficiência cardíaca: avaliação com instrumento específico. Acta Paul Enferm, São Paulo, v. 24, n. 2, p. 179-184, 2011. https://doi.org/10.1590/S0103-21002011000200004 
SANTOS, A. C. S. et al. Insuficiência cardíaca: estratégias usadas por idosos na busca por qualidade de vida. Rev. Bras. Enferm. Brasilia, v. 65, v. 5, p. 856-863, set/out. 2011.

SANTOS, M. A. et al. Dificuldades do sono relatadas por pacientes com insuficiência cardíaca. Rev LatinoAm Enfermagem, v.20, n.4, jul. /ago. 2012. https://doi.org/10.1590/S0066-782X2009000800015

SANTOS, A. C. D. Q; LIMONGI, J. E.; PEREIRA JORGE, M. L. M.; TANÚS JORGE, M.; PEREIRA, B. B.; TANNÚS JORGE, P. Aposentadorias por invalidez e Doenças Crônicas entre os servidores da Prefeitura Municipal de Uberlândia, Minas Gerais, 1990-2009. Cad Saúde Colet, Rio de Janeiro, v. 23, n. 1, p. 57-62, 2015.

SANTOS, J. J. A.; PLEWKA, J. E. A.; BROFMAN, P. R. S. Qualidade de Vida e Indicadores Clínicos na Insuficiência Cardíaca: Análise multivariada. Arq Bras Cardiol, Curitiba, v. 93, n. 2, p. 159-166, 2009.

SILVEIRA, D. F.; RIBEIRO, J. L; RAMIS, T. R. Treinamento Intermitente na Reabilitação de Pacientes com Insuficiência Cardíaca: revisão sistemática. Rev Bras Cardiol, Porto Alegre, v. 25, n. 5, p. 418-427, 2012.

SPINAR, J.; PARENICA, J.; VITOVEC, J.; WIDIMSKY, P.; LINHART, A.; FEDORCO, M.; MALEK, F.; CIHALIK, C.; SPINAROVÁ, L.; MIKLIK, R.; FELSOCI, M.; BAMBUCH, M.; DUSEK, L.; JARKOVSKY, J. Baseline characteristics and hospital mortality in the Acute Heart Failure Database (AHEAD) Main registry. Crit, [S.1.], v. 15, n. 6, 2011. Não paginado.

XAVIER, S. O. et al. Insuficiência cardíaca como preditor de dependência funcional em idosos hospitalizados. Rev. esc. enferm. USP. São Paulo, v. 49, n. 5, p. 790-796, Oct. 2015.

WORLD HEALTH ORGANIZATION. Declaração Política do Rio sobre Determinantes Sociais da Saúde. World Health Organization, Rio de Janeiro, 2011. 